\title{
Activation of lysosomal cathepsins in pregnant bovine leukocytes
}

\author{
Md Abdus Shabur Talukder ${ }^{1}$, Ahmed Zaky Balboula², Takahiro Shirozu, Sung Woo Kim³, \\ Hiroki Kunii ${ }^{1}$, Toshiyuki Suzuki ${ }^{1}$, Tsukino Ito ${ }^{1}$, Koji Kimura ${ }^{4}$ and Masashi Takahashi ${ }^{1,5}$ \\ ${ }^{1}$ Laboratory of Animal Genetics and Reproduction, Research Faculty of Agriculture, Hokkaido University, \\ Hokkaido, Japan, ${ }^{2}$ Department of Theriogenology, Faculty of Veterinary Medicine, Mansoura University, Mansoura, \\ Egypt, ${ }^{3}$ Animal Genetic Resources Research Center, National Institute of Animal Science, Namwon, Korea, \\ ${ }^{4}$ Graduate School of Environmental and Life Science, Okayama University, Okayama, Japan and ${ }^{5}$ Global Station for \\ Food, Land and Water Resources, Global Institution for Collaborative Research and Education, Hokkaido University, \\ Sapporo, Japan
}

Correspondence should be addressed to M Takahashi; Email: mmasashi@anim.agr.hokudai.ac.jp

\begin{abstract}
In ruminants, interferon-tau (IFNT)-mediated expression of interferon-stimulated genes in peripheral blood leukocytes (PBLs) can indicate pregnancy. Recently, type 1 IFN-mediated activation of lysosomes and lysosomal cathepsins (CTSs) was observed in immune cells. This study investigated the status of lysosomal CTSs and lysosomes in PBLs collected from pregnant (P) and non-pregnant (NP) dairy cows, and conducted in vitro IFNT stimulation of NP blood leukocytes. Blood samples were collected $0,7,14$ and 18 days post-artificial insemination, and the peripheral blood mononuclear cells (PBMCs) and polymorphonuclear granulocytes (PMNs) separated. The fluorescent activity of CTSB and CTSK in PMNs significantly increased with the progress of pregnancy, especially on day 18. In vitro supplementation of IFNT significantly increased the activities of CTSB and CTSK in NP PBMCs and PMNs. CTSB expression was significantly higher in PBMCs and PMNs collected from P day-18 cows than from NP cows, whereas there was no difference in CTSK expression. IFNT increased CTSB expression but did not affect CTSK expression. Immunodetection showed an increase of CTSB in P day-18 PBMCs and PMNs. In vitro stimulation of IFNT increased CTSB in NP PBMCs and PMNs. Lysosomal acidification showed a significant increase in P day-18 PBMCs and PMNs. IFNT also stimulated lysosomal acidification. Expressions of lysosome-associated membrane protein (LAMP) 1 and LAMP2 were significantly higher in P day-18 PBMCs and PMNs. The results suggest that pregnancy-specific activation of lysosomal functions by CTS activation in blood leukocytes is highly associated with IFNT during maternal and fetal recognition of pregnancy.

Reproduction (2018) 155 515-528
\end{abstract}

\section{Introduction}

There have been many trials to establish pregnancy diagnosis by direct and indirect methods such as the measurement of serum and/or milk progesterone levels (Nakao et al. 1983, Morton et al. 2010, Okumu et al. 2010), the detection of pregnancy-associated glycoproteins (PAGs) (Zoli et al. 1992), the observation of estrous behavior and the rectal palpation (RP) or ultrasonic examination of the conceptus (Fricke 2002, Romano et al. 2007). RP is a very old and still widely practiced method in large dairy animals and requires a great deal of skill and an experienced technician. During $\mathrm{RP}$, manipulation of the uterus and fetal membranes increases the risk of iatrogenic embryonic mortality and can lead to abortion (Abbitt et al. 1978, Vaillancourt et al. 1979). Currently, ultrasonography is the most widely implemented direct method of early pregnancy diagnosis in cattle, but also requires appropriate equipment and a skilled operator. Although these methods are effective, the time of detection is rather late, that is, after the maternal and fetal recognition of pregnancy, which occurs approximately during the critical period of luteolysis (Bazer et al. 1991, Thatcher et al. 1995). Therefore, a suitable indicator for early pregnancy detection is necessary.

Interferon tau (IFNT), a type 1 interferon, is a unique pregnancy recognition signal in ruminants (Bazer 2013). In cattle, mRNA transcripts of IFNT are detectable at the blastocyst stage (Rizos et al. 2003) followed by an increase of protein secretion from trophoblast cells of the conceptus around days 14-16 after fertilization and reaches a peak of secretion at days 18-19 (Thatcher et al. 1995, Mann et al. 1999, Roberts et al. 1999). The secreted IFNT alters tissues and cells to activate the signals for recognition of 
pregnancy and implantation. These IFNT-mediated signals could be possible markers for pregnancy evaluation and detection.

IFNT binds to the type 1 interferon receptor subunits (IFNAR1 and IFNAR2) and induces cell signaling via the Janus activated kinases (JAKs) and tyrosine kinase 2 (TYK2) pathways (Darnel et al. 1994, Der et al. 1998, Platanias 2005).

At the time of pregnancy recognition, IFNT affects uterine tissues by activating pregnancy-specific signaling pathways such as increases of the interferonstimulated genes (ISGs) ISG15, MX1, MX2 and so forth. (Ott et al. 1998, Hicks et al. 2003). ISG expression is clearly up-regulated in blood leukocytes in the earlier stages of pregnancy (Han et al. 2006, Gifford et al. 2007, Oliveira et al. 2008). These reports suggest that the circulating blood leukocytes are highly affected by type 1 IFN (IFNT) at the time of maternal recognition. However, since the changes in MX2 mRNA from day 0 to day 18 after artificial insemination (AI) have high variation, (Stevenson et al. 2007), it is still necessary to increase the reliability of these pregnancy predictions. Other ISGs such as 2'-5'-oligoadenylate synthetase 1 (OAS1) have been found to be a suitable pregnancy diagnosis on day 18 after $\mathrm{Al}$ in heifers, but not in cows (Green et al. 2010). Therefore, discovery and evaluation of novel pregnancy-specific extra uterine markers in the peripheral blood cells is still required. Besides, in addition to IFN-specific genes, it is necessary to develop new approaches to investigate pregnancy-specific responses in the blood cells.

Cathepsins (CTSs) are lysosomal proteases which are well known for intra/extracellular protein degradation for amino acid recruitment, and to participate in many biological processes (Turk et al. 2000) such as the bulk degradation of proteins within lysosomes. In humans, several CTSs have been identified and are categorized into three distinct groups based on the amino acid found in the active site; serine ( $A$ and $G$ ), aspartic ( $D$ and $E$ ) and cysteine (B, F, H, K, L, O, S, V, X and W) CTSs are known (Turk et al. 2001, Rossi et al. 2004). The aspartic CTSD and some of the cysteine CTSs, including CTSs B, L, and H, are ubiquitous and among the most abundant lysosomal proteases (Rossi et al. 2004). In the relationship between pregnancy and CTSs, available evidence supports the idea that a variety of proteases regulate well-defined events of trophoblast invasion in many species during implantation and placentation (Ishida et al. 2004, Walter et al. 2006). In rodents, endometrial CTSB and CTSL serve to regulate normal uterine development during implantation and placentation (Afonso et al. 1997). CTSL proteolytic activity has been found in the uteri of cats (Verhage et al. 1989, Li et al. 1991), pigs (Geisert et al. 1997) and mice (Hamilton et al. 1991, Afonso et al. 1997). Increase of CTS gene expressions and localization and activation of CTSL on days 14-18 of pregnant ovine uterus are regulated by IFNT (Song et al.
2005). However, no earlier data are currently available on the pregnancy-dependent expression patterns in CTSs mRNA in peripheral blood leukocytes (PBLs), although their presence in unspecified ovary mRNA samples has been reported previously (Petanceska \& Devi 1992, Bromme \& Okamoto 1995, Rantakokko et al. 1996, Kirscheke et al. 1998, Soderstrom et al. 1999).

Recently, an in vitro study has demonstrated that lysosomal proteases are activated by cytokines such as type 1 IFN (IFNB) in cultured mouse macrophages (Creasy et al. 2011). Type 1 IFN-stimulated pathways may be involved in several types of cells including blood leukocytes, because they exist in many types of somatic cell. Lysosomes contain a considerable number of proteases, the best known of which are the CTSs which are active in an acidic environment (Kirschke et al. 1998). Activation of lysosomes is correlated with activation of CTSs in the immune cells (Creasy et al. 2011).

In cattle, lysosomal activity during early pregnancy, including the gene expression patterns of lysosomal membranes and lysosomal proteases (CTSB and CTSK), and the presence of CTSB proteins in blood leukocytes remain unknown. Thus, the current investigation was undertaken to investigate the status of lysosomal CTSs and lysosomes in bovine leukocytes during early pregnancy, as well as to investigate the effects of IFNT.

\section{Materials and methods}

\section{Animals}

The animals used in this study were the multiparous Holstein Friesian cows which belong to the Hokkaido University Dairy Farm. All animal handling procedures were approved by the Hokkaido University Guidelines for the Care and Use of Experimental Animals (16-0019).

\section{Collection of blood samples and isolation of peripheral blood mononuclear cells (PBMCs) and polymorphonuclear granulocytes (PMNs)}

Healthy lactating dairy cows showing natural heat were used for Al without estrous synchronization program. After Al, blood samples were collected from the jugular vein into tubes containing heparin on day (d) 0, d7, d14 and d18. Pregnancy was confirmed by transrectal ultrasonography 40-60 days after AI. For the isolation of PBMCs, whole blood was mixed with an equal volume of phosphate buffer solution (PBS). Three milliliters of Lymphocyte Separation Medium 1077 (PromoCell, $\mathrm{GmbH}$ Sickingenstr, Heidelberg, Germany) was added into a separate tube. The blood cell suspension containing tube was centrifuged at $440 \mathrm{~g}$ for $40 \mathrm{~min}$ at room temperature. After centrifugation, the supernatant was carefully removed and the layer in the interphase containing mononuclear cells was carefully aspirated and transferred into another tube. The mononuclear cell suspension was washed with PBS by centrifugation at $440 \mathrm{~g}$. After washing, PBMCs were transferred 
into Roswell Park Memorial Institute (RPMI) 1640 medium containing 5\% fetal bovine serum (FBS) for further analysis.

For isolation of the PMNs, $10 \mathrm{~mL}$ of RBC lyses buffer (The buffer solution containing $\mathrm{NH}_{4} \mathrm{Cl}: 87.06 \%, \mathrm{NaHCO}_{3}: 12.54 \%$ and EDTA2Na:0.40\% w/v) was added into the same tube and pipetted carefully to rupturing the erythrocytes. After centrifugation, the supernatant was removed. This step was repeated until white precipitation, a layer of granulocytes (PMNs), was observed. The PMN precipitate was washed with PBS and the separated PBMCs and PMNs samples were lysed in ISOGEN-II (Nippon Gene, Toyama, Japan) and stored at $-80^{\circ} \mathrm{C}$ for further RNA extraction. The cells were then used for measuring CTSB and CTSK activity, gene expression analysis, immunostaining and lysosomal activity.

\section{In vitro culture and stimulation of PBMCs and PMNs by IFNT}

PBMCs and PMNs were isolated from whole blood collected from the jugular vein of healthy lactating non-Al cows at mid-late estrous stage. The cells were cultured in the RPMI 1640 containing 5\% FBS with or without recombinant IFNT (rbIFNT) which was produced by Escherichia coli using cDNA (bTP-509A, gifted by Dr RM Roberts, University of Missouri, Columbia, MO, USA) and expression vector (Imakawa et al. 1987). Antiviral activity determined by MDBK cells was $8 \times 10^{6} \mathrm{IU} / \mathrm{mL}$. Final concentration of $1000 \mathrm{IU} / \mathrm{mL}$ IFNT was designed based on the antiviral activity of plasma collected from 15 days of pregnant ovine uterine vein (500-1000 U/ $\mathrm{mL}$ ) that might be a possible stimulating concentration to leukocytes locally (Oliveira et al. 2008). The cells were then cultured for 3,6 and $12 \mathrm{~h}$ at $38.5^{\circ} \mathrm{C}$ in a $\mathrm{CO}_{2}$ incubator. At the end of each treatment, cells were collected and centrifuged at $10000 \mathrm{~g}$ for $10 \mathrm{~min}$, followed by washing twice with PBS. For measuring CTSs activity, $10 \mu \mathrm{L}$ cell suspensions were removed from whole cell suspension and $200 \times$ diluted CTSs substrates were added and gently mixed. Cells were cultured for $40 \mathrm{~min}$ at $38.5^{\circ} \mathrm{C}$ in a $\mathrm{CO}_{2}$ incubator. After incubation, the samples were washed twice with PBS solution. The cells were then used for measuring CTSB and CTSK activity, gene expression analysis and immunostaining of CTSB.

\section{RNA extraction, $C D N A$ synthesis and $q P C R$}

Total RNA of PBMCs and PMNs from in vivo collected and in vitro -cultured samples was separately extracted and stored at $-80^{\circ} \mathrm{C}$ until analysis. After standardizing the RNA quantity using a NanoDrop spectrophotometer (Thermo Fisher Scientific), cDNA was synthesized with a ReverTra Ace qPCR RT Master Mix (TOYOBO, Osaka, Japan). The synthesized cDNA was stored at $-30^{\circ} \mathrm{C}$. To assess the gene expression, quantitative PCR (qPCR) was performed using the KAPA SYBR FAST PCR Kit optimized for Roche Light Cycler nano (Roche Diagnostics $\mathrm{GmbH}$ ). Primers for ISG 15 as a pregnancy-positive marker, CTSs $(B$ and $K)$ and lysosomal-associated membrane protein $(L A M P)$ 1, 2 were designed and commercially synthesized based on reported sequences.

The reactions were carried out in a normal qPCR 8 strip tube, in a total volume of $10 \mu \mathrm{L}$ containing $1 \mu \mathrm{L}(0.5 \mu \mathrm{L}$ reverse and $0.5 \mu \mathrm{L}$ forward) of each primer, $5 \mu \mathrm{L}$ KAPA SYBR FAST qPCR Kit and $4 \mu \mathrm{L}$ of $\mathrm{CDNA}$, and subjected to the following cycling condition: a denaturation step at $95^{\circ} \mathrm{C}$ for $30 \mathrm{~s}$, an amplification step of 45 cycles at $95^{\circ} \mathrm{C}$ for $10 \mathrm{~s}, 55^{\circ} \mathrm{C}$ for $15 \mathrm{~s}$ and $72^{\circ} \mathrm{C}$ for $30 \mathrm{~s}$. The expression level of each gene was normalized using glyceraldehyde-3 phosphate dehydrogenase (GAPDH) and ACTB as the internal standard. The qPCR primer sequences used are presented in Table 1.

\section{Detection of activities of CTSB and CTSK in PBMCs and PMNs}

Detection of CTSs activity was performed with fluorescent substrates. Cell suspensions $(10 \mu \mathrm{L})$ of both PBMCs and PMNs were used. Magic Red CTSs ( $B$ and $K$ ) assay kits $\left(M R-R R_{2}\right.$ and MR-LR ${ }_{2}$ ) (Immunochemistry Technologies, LLC, Bloomington, $M N$, USA) were prepared by diluting the Magic Red stock solutions to 200× with RPMI 1640 containing 5\% FBS. To stain the nuclei, $1 \mu \mathrm{L}$ of Hoechst33342 was added, and the tubes were incubated for $40 \mathrm{~min}$ in a $\mathrm{CO}_{2}$ incubator at $38.5^{\circ} \mathrm{C}$. After incubation, the samples were washed twice with PBS solution. A $10 \mu \mathrm{L}$ sample was dropped onto a slide glass with a cover slip $(18 \times 18 \mathrm{~mm})$ and immediately placed under a fluorescence microscope (Keyence, Osaka, Japan) using a 550-nm excitation filter at 400×. All images in both PBMCs and PMNs were captured in the same exposure conditions.

Table 1 List of primer and primer sequence used for RT-qPCR.

\begin{tabular}{|c|c|c|c|c|c|}
\hline Primer name & & Primer sequence $\left(5^{\prime}-3^{\prime}\right)$ & $\operatorname{Tm}\left({ }^{\circ} \mathrm{C}\right)$ & Product length (bp) & GenBank accession number \\
\hline ISG15 & $\begin{array}{l}\text { FWD: } \\
\text { REV: }\end{array}$ & $\begin{array}{l}\text { TGAGGGACTCCATGACGGTA } \\
\text { GCTGGAAAGCAGGCACATTG }\end{array}$ & $\begin{array}{l}59.67 \\
60.39\end{array}$ & 72 & AC_000173.1 \\
\hline CTSB & $\begin{array}{l}\text { FWD: } \\
\text { REV: }\end{array}$ & $\begin{array}{l}\text { CACTTGGAAGGCTGGACACA } \\
\text { GCATCGAAGCTTTCAGGCAG }\end{array}$ & $\begin{array}{l}66.30 \\
67.20\end{array}$ & 141 & AC_000180.1 \\
\hline CTSK & $\begin{array}{l}\text { FWD: } \\
\text { REV: }\end{array}$ & $\begin{array}{l}\text { TCCGGCCACATTATCCACAC } \\
\text { ACCACAGGCAGCAGTAGAAC }\end{array}$ & $\begin{array}{l}67.9 \\
61.9\end{array}$ & 99 & AC_000174.1 \\
\hline LAMP1 & $\begin{array}{l}\text { FWD: } \\
\text { REV: }\end{array}$ & $\begin{array}{l}\text { GTGAAGAATGGCAACGGAC } \\
\text { GCATCAGCTGGACCTCGTAA }\end{array}$ & $\begin{array}{l}66.6 \\
65.2\end{array}$ & 250 & AC_000169.1 \\
\hline LAMP2 & $\begin{array}{l}\text { FWD: } \\
\text { REV: }\end{array}$ & $\begin{array}{l}\text { AAGAGCAGACCGTTTCCGTG } \\
\text { CGAACACTCTTGGGCAGTAG }\end{array}$ & $\begin{array}{l}66.5 \\
62.4\end{array}$ & 110 & AC_000187.1 \\
\hline GAPDH & $\begin{array}{l}\text { FWD: } \\
\text { REV: }\end{array}$ & $\begin{array}{l}\text { CACССТCAAGATTGTCAGCA } \\
\text { GGTCATAAGTCCCTCCACGA }\end{array}$ & $\begin{array}{l}63.90 \\
63.80\end{array}$ & 103 & AC_000162.1 \\
\hline$A C T B$ & $\begin{array}{l}\text { FWD: } \\
\text { REV: }\end{array}$ & $\begin{array}{l}\text { TGGACTTCGAGCAGGAGATG } \\
\text { GTAGAGGTCCTTGCGGATGT }\end{array}$ & $\begin{array}{l}65.5 \\
63.0\end{array}$ & 221 & AC_000182.1 \\
\hline
\end{tabular}


The fluorescence intensity was measured by ImageJ analysis software (National Institutes of Health, Bethesda, MD, USA).

\section{Immunodetection of CTSB in in vivo collected and in vitro cultured PBMCs and PMNs}

Separated PBMCs and PMNs collected from day 18 pregnant and NP cows, and from samples after $6 \mathrm{~h}$ of in vitro stimulation by IFNT, were fixed in $4 \%$ paraformaldehyde (PFA) in $0.5 \mathrm{~mL}$ tubes for $24 \mathrm{~h}$ at $4{ }^{\circ} \mathrm{C}$ and processed using standard procedures. Cells were washed and then permeabilized with PBS containing $0.2 \%$ TritonX 100 (PBST) for $10 \mathrm{~min}$. Then, the cells were treated for blocking with PBST containing 1\% BSA for $1 \mathrm{~h}$ at room temperature. After blocking, incubation with the primary CTSB polyclonal antibody (anti-rabbit IgG, 1:1000) (Calbiochem, EMD Millipore Corporation) was performed for $2 \mathrm{~h}$ at room temperature. The cells were also incubated with the fluorescence in conjugated secondary antibody (donkeyantirabbit IgG, 1:1000) (GE Healthcare Bio Sciences AB) for $1 \mathrm{~h}$ at room temperature in dark conditions. A negative control was set by substituting the primary antibody with PBST+1\% BSA at the respective dilution. Between each step, cells were washed three times in PBS for 5 min. After washing with PBS, the cell suspension was dropped onto a glass slide and covered with a cover glass $(18 \times 18 \mathrm{~mm})$. All images were captured with a fluorescent microscope (Leica Microsystems) in $1.5 \mathrm{~s}$ exposures time using a 550-nm excitation filter at $400 \times$. The fluorescence intensity was measured by ImageJ analysis software (National Institutes of Health).

\section{Assessment of lysosomal activity in PBMCs and $P M N$ s collected from pregnant and non-pregnant day 18 cows}

Separated PBMCs and PMNs from day 18 pregnant and NP cows or from samples after $6 \mathrm{~h}$ of in vitro stimulation by IFNT were incubated in pre-warmed RPMI 1640 medium with $1-\mu \mathrm{M}$ solution of DMSO diluted with LysoSensor Green DND 189 (L7535, Invitrogen by Thermo Fisher Scientific, Life Technologies) for $15 \mathrm{~min}$ at $38.5^{\circ} \mathrm{C}$ in a $\mathrm{CO}_{2}$ incubator. Then, Hoechst 33342 (Sigma-Aldrich) was added to stain the nuclei. After incubation, samples were washed twice with PBS solution. After washing, $10 \mu \mathrm{L}$ of cell suspension was put onto a glass slide, covered with cover glass $(18 \times 18 \mathrm{~mm})$ and observed under the fluorescence microscope (Leica Microsystems) using a 590-nm excitation filter at 400×. The fluorescence images were captured with similar exposure conditions and analyzed by Image) Software (National Institutes of Health).

\section{Statistical analysis}

Data were analyzed using GraphPad prism version 5 for Windows (GraphPad Software, www.graphpad.com) and were presented as the mean \pm S.E.M. One-way ANOVAs and Student's $t$ tests were performed. $P$ values less than $0.05(P<0.05)$ were considered to represent statistically significant differences.

\section{Results}

\section{Activities of CTSB and CTSK in PBMCs and PMNs in pregnant and non-pregnant cows}

Fluorescence intensity of CTSB and CTSK activity were detected in both PBMCs and PMNs (Fig. 1A and B). The fluorescence intensity of CTSB activity was higher in PBMCs $(P<0.05)$ and PMNs $(P<0.01)$ after $\mathrm{d} 14$ when compared to $d 0$ and $d 7$ of pregnancy, but was not different for cells from NP cows (Fig. 2A and B). Similar to CTSB, strong fluorescence from CTSK activity was detected in the PBMCs and PMNs of pregnant cows (Fig. 1B). The fluorescence intensity of CTSK in PMNs was higher $(P<0.05)$ on $\mathrm{d} 14$ and $\mathrm{d} 18$ of pregnancy than on $\mathrm{d} 0$ and $\mathrm{d} 7$. The fluorescence intensity of CTSK was
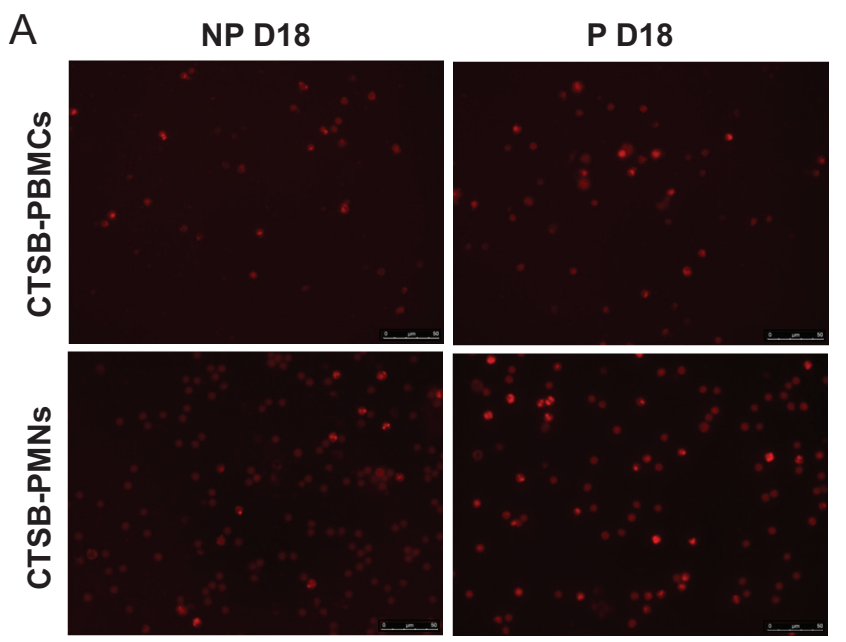

B
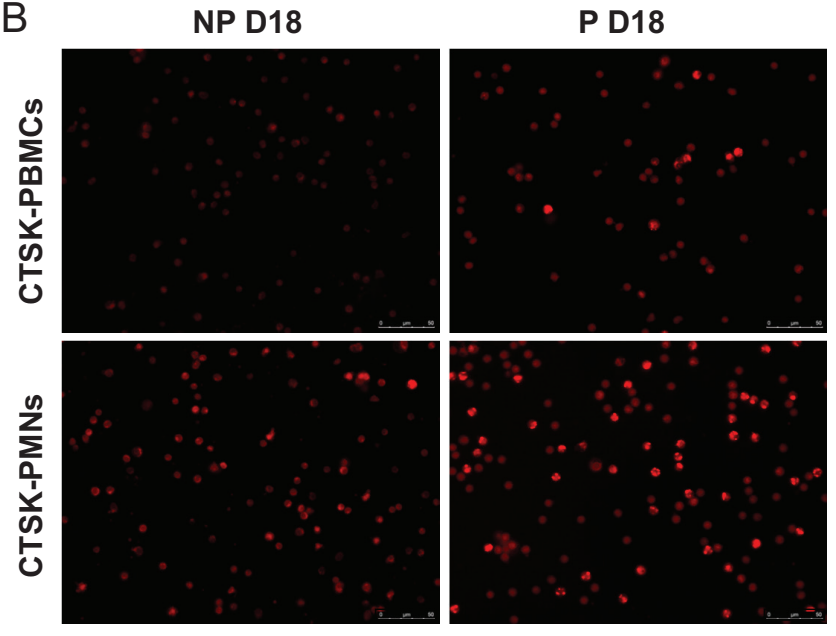

Figure 1 Activities of CTSB and CTSK in PBMCs and PMNs collected from d1 8 pregnant and non-pregnant cows. Photos show the fluorescence images of CTSB (A) and CTSK (B) in PBMCs and PMNs on d18 non-pregnant (NP) and pregnant (P) cows. After the cells were incubated with fluorescence substrate for CTSB and CTSK, cells were washed, and the fluorescence activities were detected by a fluorescent microscope using a 550-nm excitation filter at $400 \times$. The scale bar represents $50 \mu \mathrm{m}$. 
A

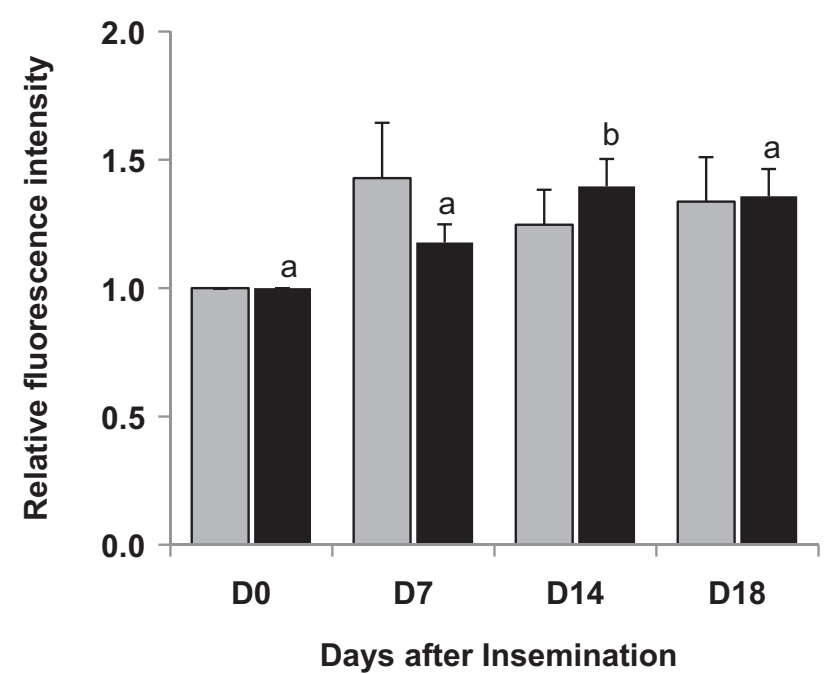

C

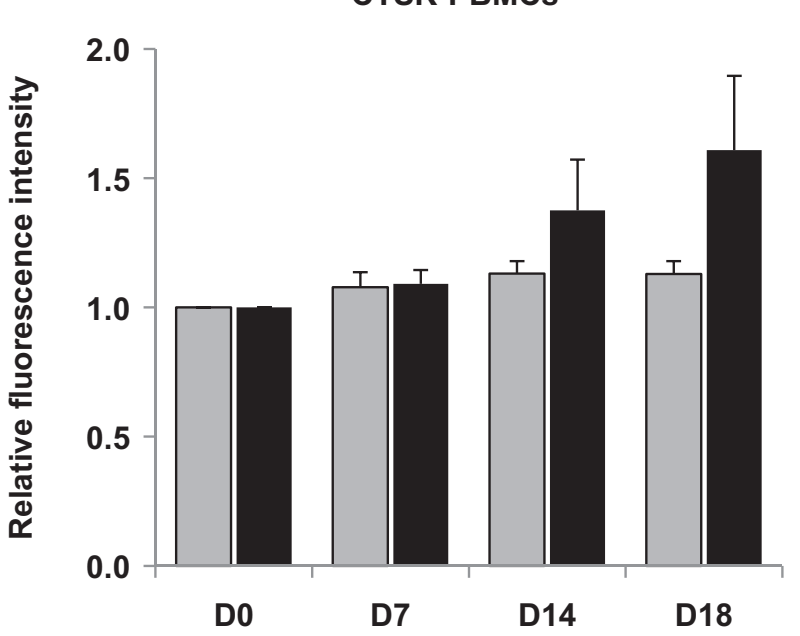

Days after Insemination
B

CTSB-PMNS

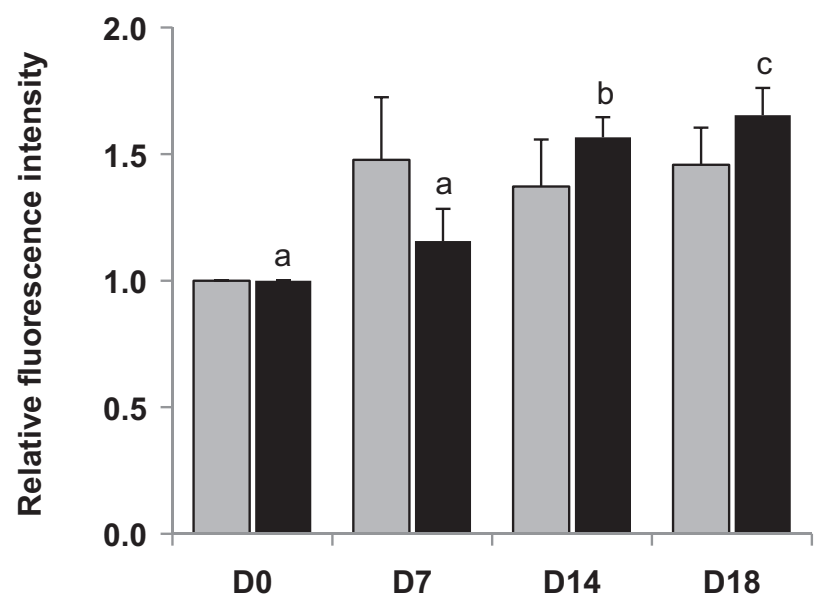

Days after Insemination

D

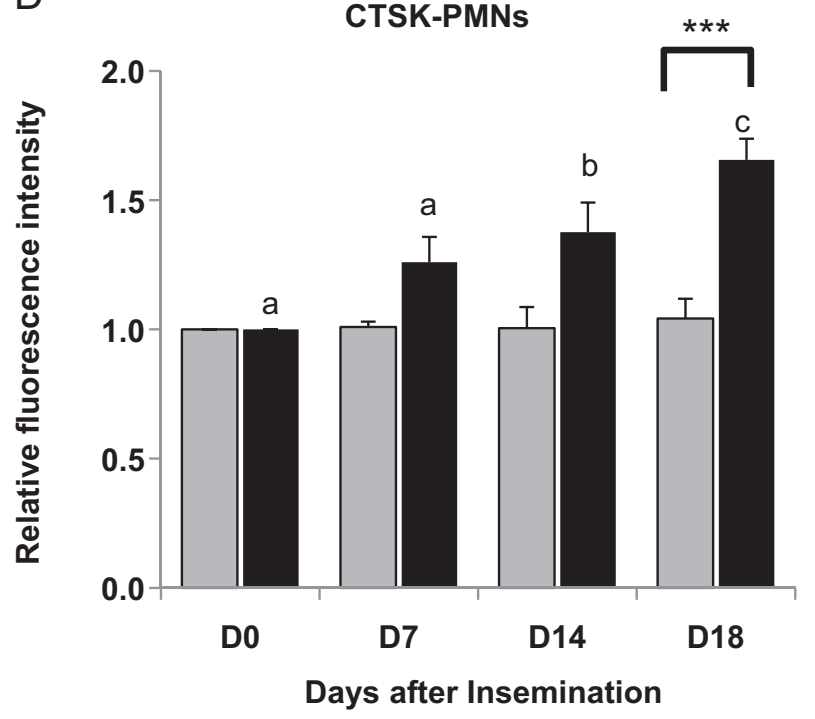

Figure 2 Changes in the activities of CTSB and CTSK in PBMCs and PMNs collected from pregnant and non-pregnant cows. Relative activities of CTSB in PBMCs (A) and PMNs (B), and of CTSK in PBMCs (C) and PMNs (D) on d 0-18 after insemination in dairy cows that were later diagnosed as pregnant (black bars) or not pregnant (gray bars). Ten cows ( 5 for pregnant and 5 for non-pregnant) were used for detecting the activities of CTSB and CTSK in PBMCs and PMNs. All data are shown as the mean \pm S.E.M. Different letters indicate significant differences $(P<0.05)$ among the days in pregnant $(\mathrm{P})$ cows according to ANOVA followed by Fisher's as a multiple-comparison test. Asterisks indicate differences $\left({ }^{* *} P<0.0001\right.$, Student's $t$ test) between non-pregnant (NP) and pregnant $(\mathrm{P})$ cows on the same days after Al.

higher $(P<0.001)$ in the pregnant d18 PMNs than it was in NP d18 cells (Fig. 2D).

\section{Effect of IFNT stimulation on activity of CTSB and CTSK in PBMCs and PMNs obtained from non-Al cows}

An increase in CTSB activity was observed both in PBMCs and PMNs after the addition of IFNT (Fig. 3A). Increases of fluorescence intensity were observed in PBMCs $(P<0.05)$ after $12 \mathrm{~h}$ and in PMNs $(P<0.001) 6 \mathrm{~h}$ after stimulation with IFNT (Fig. 3B and C). In addition,
IFNT increased CTSK activity in both PBMCs and PMNs (Fig. 4A). Fluorescence intensity was increased in PBMCs after $6 \mathrm{~h}(P<0.05)$ and in PMNs after $3 \mathrm{~h}(P<0.05)$ of IFNT treatment (Fig. 4B and C).

\section{Gene expression of CTSB and CTSK in PBMCs and $P M N s$ from non-pregnant and pregnant cows}

To confirm that the leukocytes of pregnant cows were affected by IFNT stimulation, expression of ISG15, a positive marker gene of pregnancy, was detected. In 
A $\quad$ oh

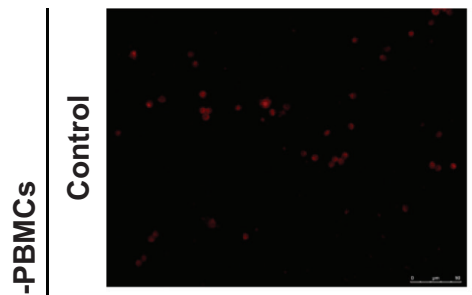

它

点
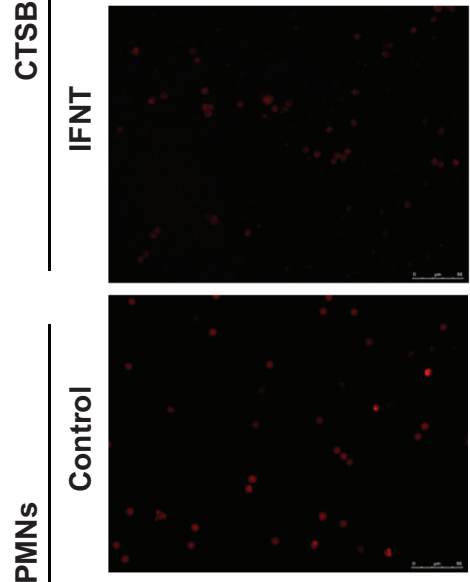

它
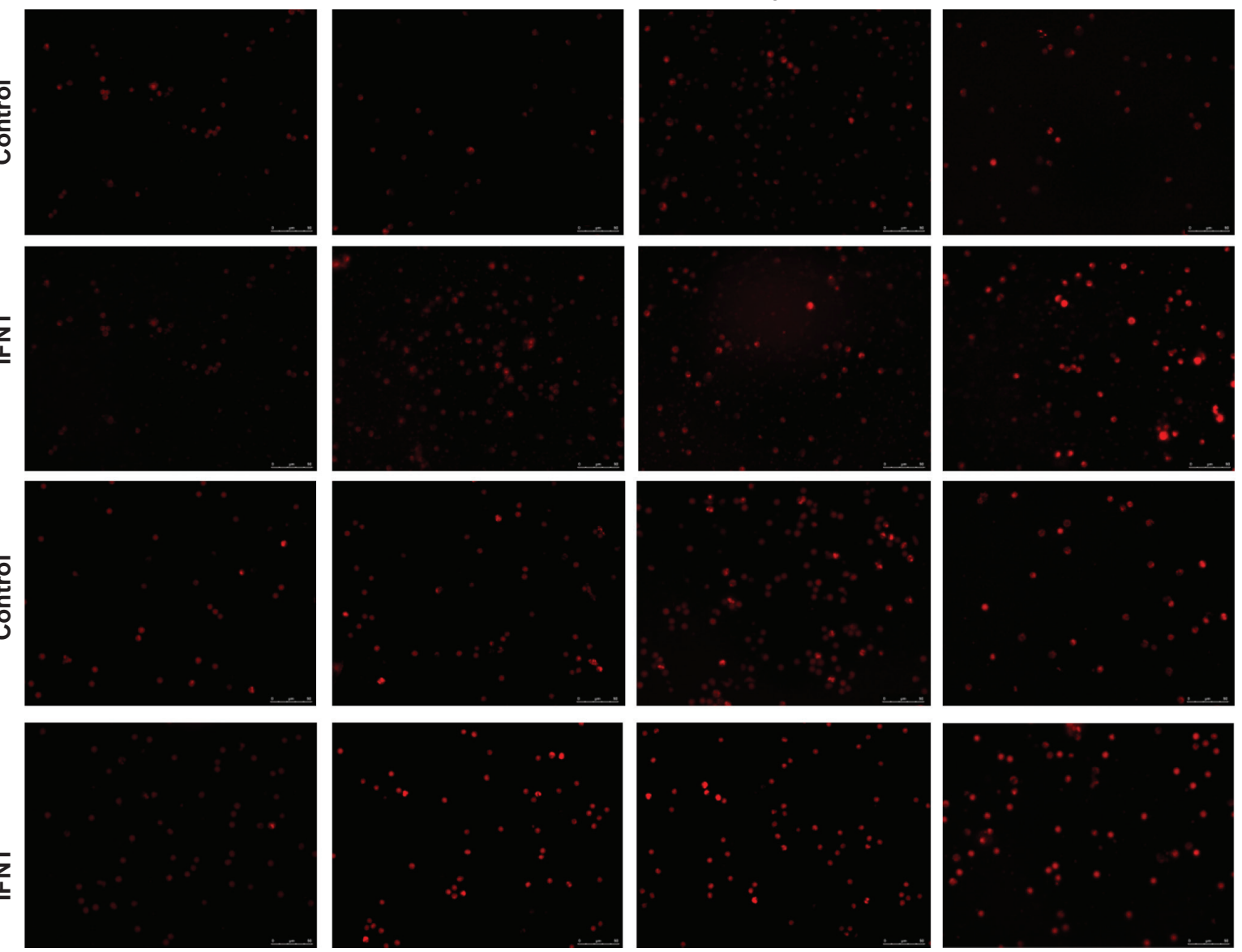

B

CTSB-PBMCs

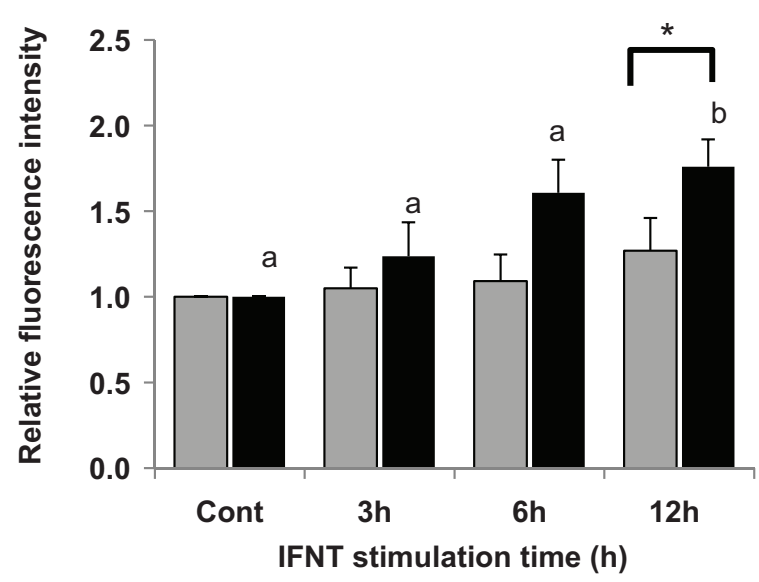

C

CTSB-PMNs

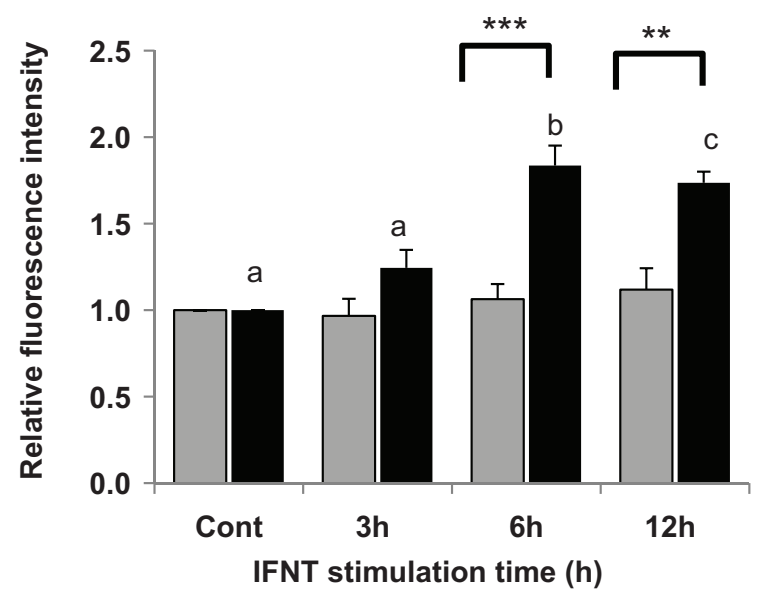

Figure 3 CTSB activity of non-pregnant PBMCs and PMNs after in vitro stimulation by IFNT. Photos show the fluorescence images of CTSB in PBMCs and PMNs after 3, 6 and $12 \mathrm{~h}$ of IFNT stimulation (A). Relative fluorescence intensity of CTSB activity of PBMCs (B) and PMNs (C). After IFNT stimulation, cells were incubated with Magic Red treatment. The CTSB activity was detected using a 550-nm excitation filter at 400×. The scale bar represents $50 \mu \mathrm{m}$. Gray bars show the fluorescence intensity of the non-treated group and black bars the IFNT-treated group. All data are shown as the mean \pm S.E.M. Different letters indicate difference $(P<0.05)$ among IFNT treatment times according to ANOVA followed by Fisher's as a multiple-comparison test. Experiment was repeated 4 times. Asterisks indicate differences $\left({ }^{*} P<0.05,{ }^{* *} P<0.01,{ }^{* * *} P<0.0001\right.$, Student's $t$ test) between groups with the same incubation time. 
A
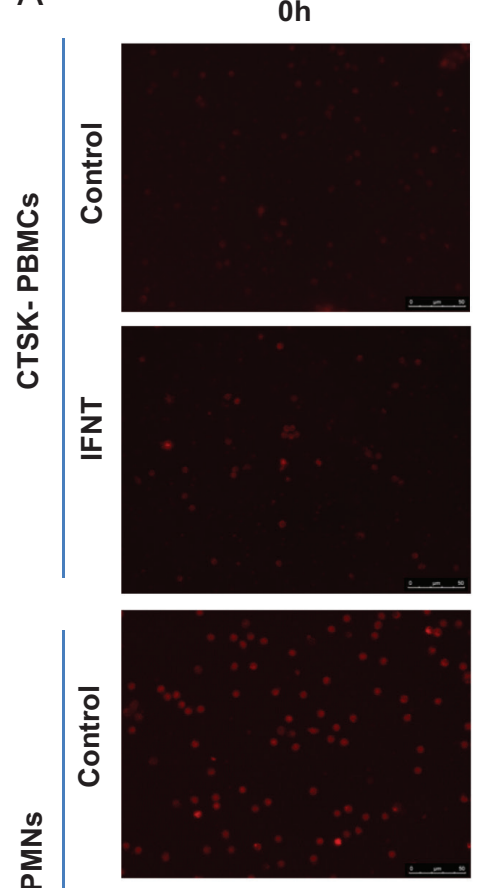

ஸ

㫖

B

CTSK-PBMCs

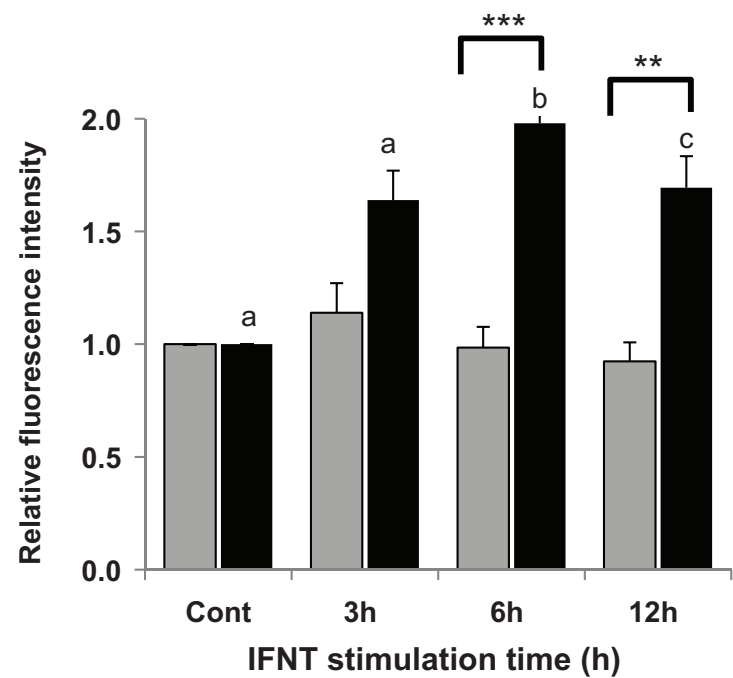

$6 h$
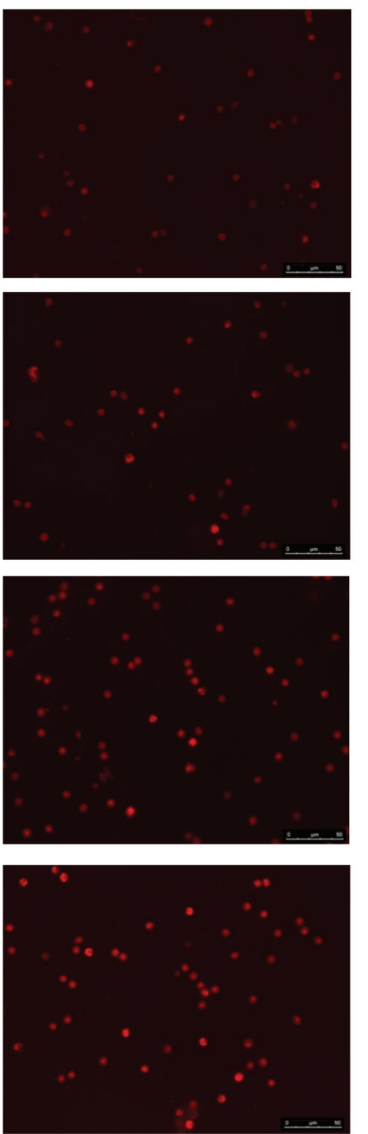

C

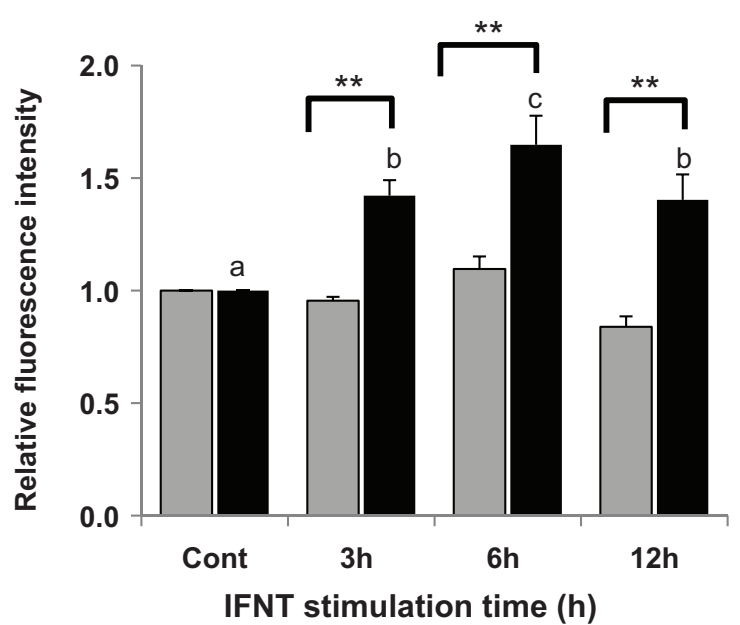

Figure 4 CTSK activity of non-pregnant PBMCs and PMNs after in vitro stimulation of IFNT. Photos show the fluorescence images of CTSK in PBMCs and PMNs after 3, 6 and $12 \mathrm{~h}$ of IFNT stimulation (A). Relative fluorescence intensity of CTSK activity of PBMCs (B) and PMNs (C). After IFNT stimulation, cells were incubated with Magic Red treatment. The CTSK activity was detected using a 550-nm excitation filter at 400x. The scale bar represents $50 \mu \mathrm{m}$. Gray bars show the fluorescence intensity of the non-treated group and black bars the IFNT-treated group. All data are shown as the mean \pm S.E.M. Different letters indicate difference $(P<0.05)$ among the IFNT treatment times according to ANOVA followed by Fisher's as a multiple-comparison test. Experiment was repeated 3 times. Asterisks indicate differences $\left(* * P<0.01,{ }^{* * * P} P<0.0001\right.$, Student's $t$ test.) between groups with the same incubation time. 

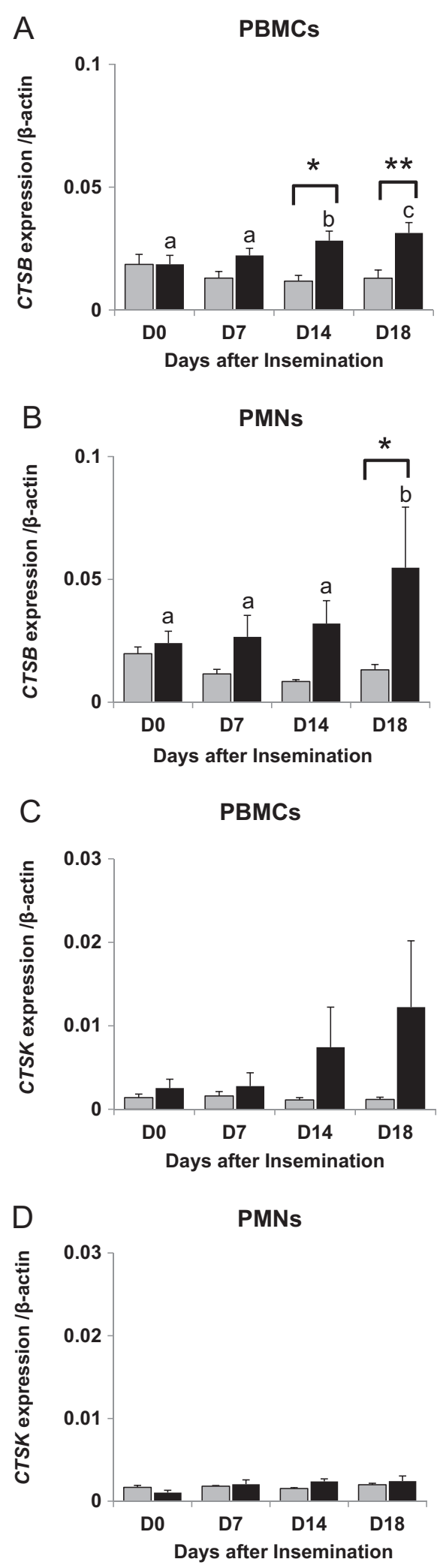

Figure 5 Expression of CTSB and CTSK mRNA in PBMCs and PMNs of pregnant and non-pregnant cows after $\mathrm{Al}$. The graphs show the expression levels of CTSB in PBMCs (A) and PMNs (B), and CTSK in PBMCs (C) and PMNs (D), standardized by ACTB. Gray bars show
PBMCs, ISG15 mRNA expression levels were higher $(P<0.05)$ on $\mathrm{d} 18$ in pregnant cows than they were in other stages (Supplementary Fig. 1A, see section on supplementary data given at the end of this article). In PMNs, expression of ISG15 mRNA was higher $(P<0.05)$ on d18 than it was at other stages (Supplementary Fig. 1B).

Expression of the CTSB gene in PBMCs was higher on $\mathrm{d} 14(P<0.05)$ and $\mathrm{d} 18(P<0.01)$ in pregnant cows than it was in NP cows, respectively (Fig. 5A). CTSB expression was also higher $(P<0.05)$ in PMNs on $\mathrm{d} 18$ of pregnancy than in those collected from NP cows (Fig. 5B). CTSK mRNA expression levels were not affected in either PBMCs or PMNs (Fig. 5C and D).

\section{Effect of IFNT stimulation on the expression of CTSB and CTSK in PBMCs and PMNs obtained from non-Al cows}

Expression of CTSB mRNA in PBMCs and PMNs was higher $(P<0.05)$ after $6 \mathrm{~h}$ of IFNT stimulation (Fig. 6A and B). CTSK mRNA level was not affected by IFNT treatment (Fig. 6C and D). ISG15 mRNA expression was increased in both PBMCs $(P<0.0001)$ and PMNs $(P<0.01)$ by IFNT treatment $(P<0.01)$ (Supplementary Fig. 2C and D).

\section{Immunohistochemistry of CTSB protein in PBMCs and PMNs}

After immunostaining, CTSB was clearly detected in in vivo collected PBMCs and PMNs (Fig. 7A). Image analysis showed that fluorescent intensities of CTSB were higher in pregnant PBMCs $(P<0.001)$ and PMNs $(P<0.05)$, respectively, than those in NP cows (Fig. 7B and $\mathrm{C})$. In vitro stimulation with IFNT also showed an increase of fluorescence in PBMCs $(P<0.05)$ and PMNs $(P<0.01)$, respectively, compared with non-stimulated control cells (Fig. 7D, E and F).

\section{Lysosomal activity in PBMCs and PMNs}

Clear fluorescence indicating the acidification status of lysosomes was observed in both PBMCs and PMNs (Fig. 8A). The fluorescence intensities of PBMCs and PMNs from pregnant cows were higher $(P<0.05)$ than those from NP cows (Fig. 8B and C). In vitro stimulation

the gene expression levels of non-pregnant (NP) cows, and black bars show the pregnant $(\mathrm{P})$ cows. Twelve cows $(6$ for pregnant and 6 for non-pregnant) were used for detecting the activities of CTSB and CTSK in PBMCs and PMNs. All data are shown as the mean \pm S.E.M. Different letters indicate differences $(P<0.05)$ among the days in pregnant $(\mathrm{P})$ cows according to ANOVA followed by Fisher's as a multiple-comparison test. Asterisks indicate differences $\left({ }^{*} P<0.05\right.$, ${ }^{* *} P<0.01$, Student's $t$ test) between non-pregnant (NP) and pregnant (P) cows on the same days after Al. 


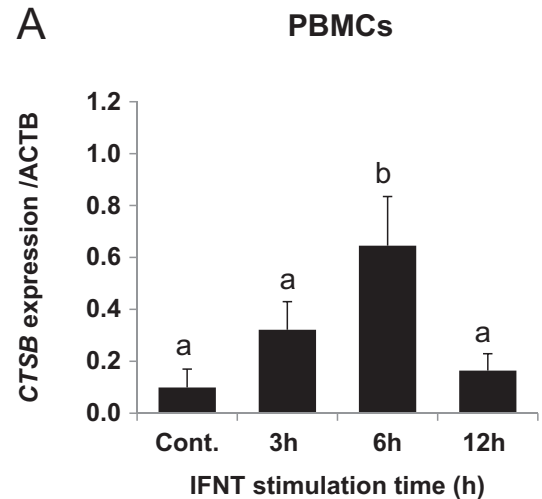

B PMNs
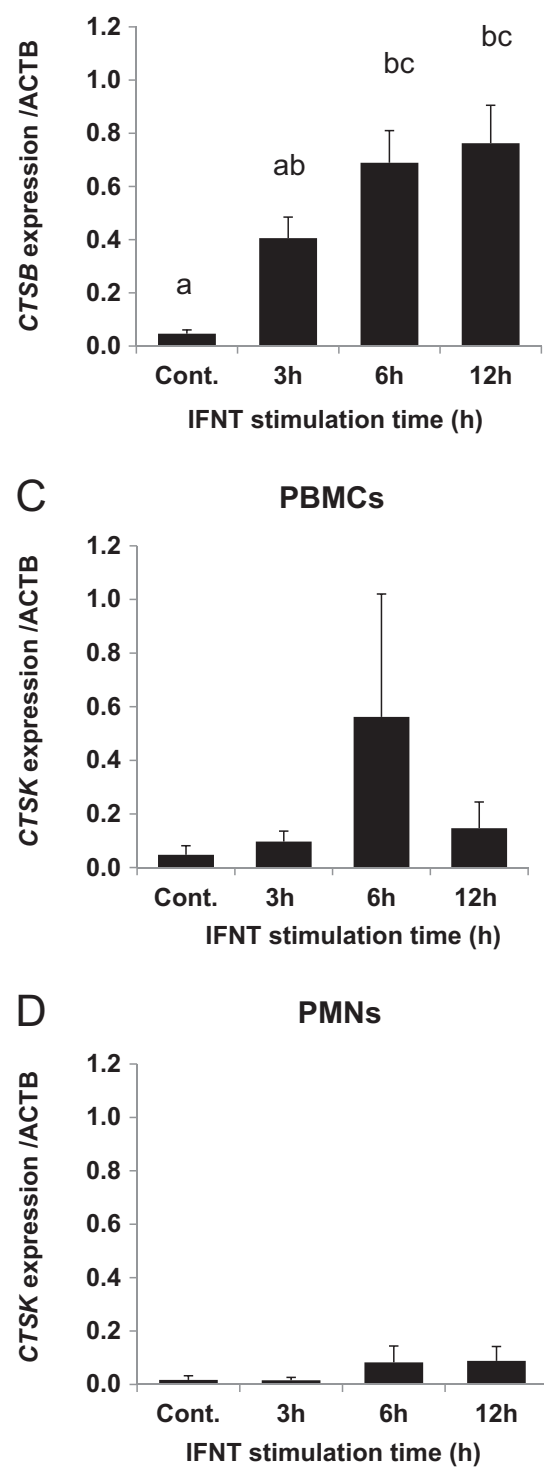

Figure 6 Effect of IFNT stimulation on the expression of CTSB and CTSK in PBMCs and PMNs obtained from non-Al cows. Expression levels of CTSB in PBMCs (A) and PMNs (B), and CTSK in PBMCs (C) and PMNs (D), using RT-qPCR standardized with the reference gene of both cells by IFNT showed increases $(P<0.01)$ in fluorescence intensity compared with non-stimulated control cells (Fig. 8D, E and F).

\section{Gene expression of LAMP1 and LAMP2 in PBMCs and $P M N$ s from 118 of non-pregnant and pregnant cows}

Expression of $L A M P 1$ was higher $(P<0.05)$ in both PBMCs and PMNs on d18 in pregnant cows (Fig. 9A and B). Similarly, expression of $\angle A M P 2$ was higher in PBMCs $(P<0.05)$ and PMNs $(P<0.01)$ of d18 pregnant cows, respectively (Fig. 9C and D).

\section{Discussion}

Although many methods are used for the diagnosis of pregnancy, generally, all these techniques are only applicable three weeks after fertilization (Romano et al. 2007, Morton et al. 2010, Okumu et al. 2010). Exploring new candidate genes which are induced by type 1 interferon (that is, IFNT) and their potential use as markers of pregnancy through immune cells increases the possibility of early diagnosis of pregnancy in cattle. In the present study, we investigated the pregnancyspecific lysosomal functions associated with CTSs, lysosomal proteases and their regulations by IFNT in PBMCs and PMNs using in vivo and in vitro experiments.

In the present study, in vivo analysis revealed a significant increase in the activity of CTSs B and $\mathrm{K}$ in PMNs in pregnant cows on d18 compared with that of cells collected from d0 post-Al cows. To confirm whether the pregnancy-related CTSs activation is caused by IFNT, an in vitro study was conducted. As expected, the fluorescence intensity of these CTSs enzyme activity was increased by IFNT stimulation both in PBMCs and PMNs. These results strongly suggest that the activation of the CTSs of immune cells could be stimulated by IFNT.

To confirm that the increase of CTS activity is pregnancy-specific in blood leukocytes, ISG 15 was also analyzed as a potential positive marker of pregnancy in vivo. Its response to in vitro stimulation using rbIFNT, which has been well established as a suitable early pregnancy detection marker in many studies (Green et al. 2010, Shirasuna et al. 2012, Puglisi et al. 2014), was also assessed. Our results showed high ISG15 expression levels, indicating that the PBMCs and PMNs were affected by IFNT stimulation both in in vivo and in vitro (Supplementary Figs 1 and 2). Therefore, the increase of CTS activities on d18 was very possibly due to IFNT-mediated stimulation, as its secretion is maximal at this stage.

ACTB. IFNT stimulation was performed for 3, 6 and $12 \mathrm{~h}$. Experiment was repeated 7 times for CTSB and 5 times for CTSK, respectively. All data are shown as the mean \pm S.E.M. Different letters indicate differences $(P<0.05)$ among the stimulation times by ANOVA followed by Fisher's PLSD procedure as a multiple-comparison test. 
A
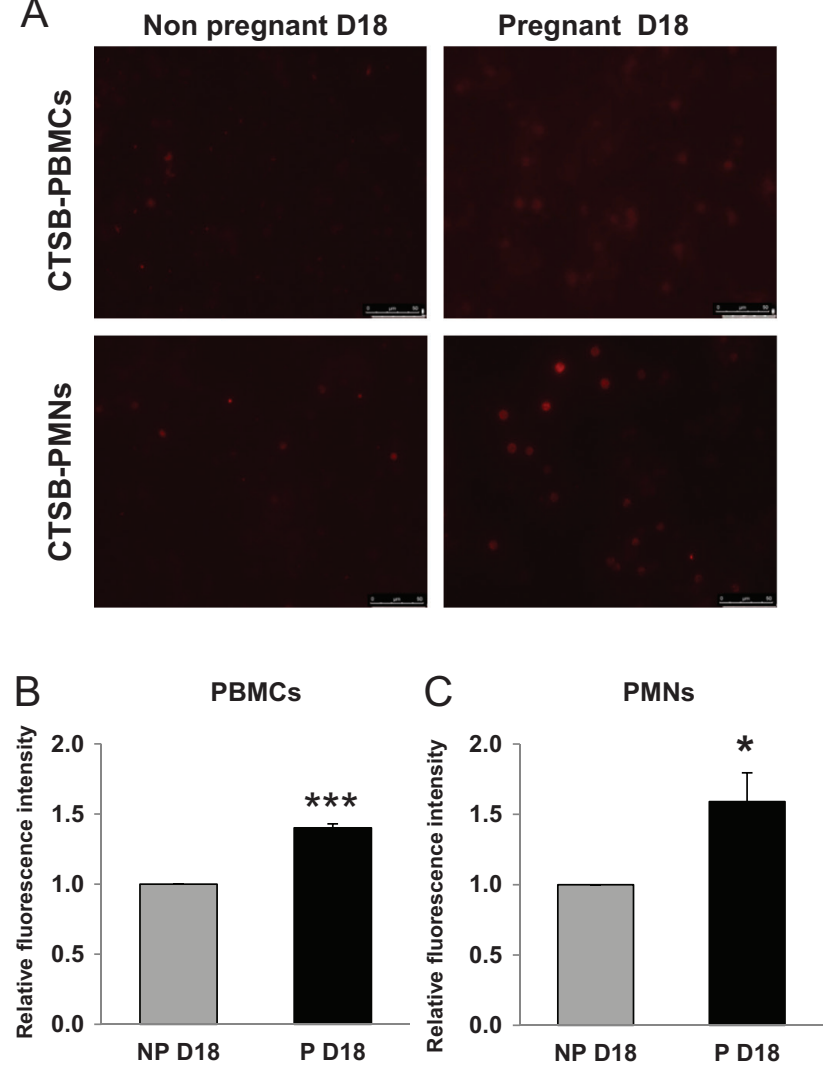
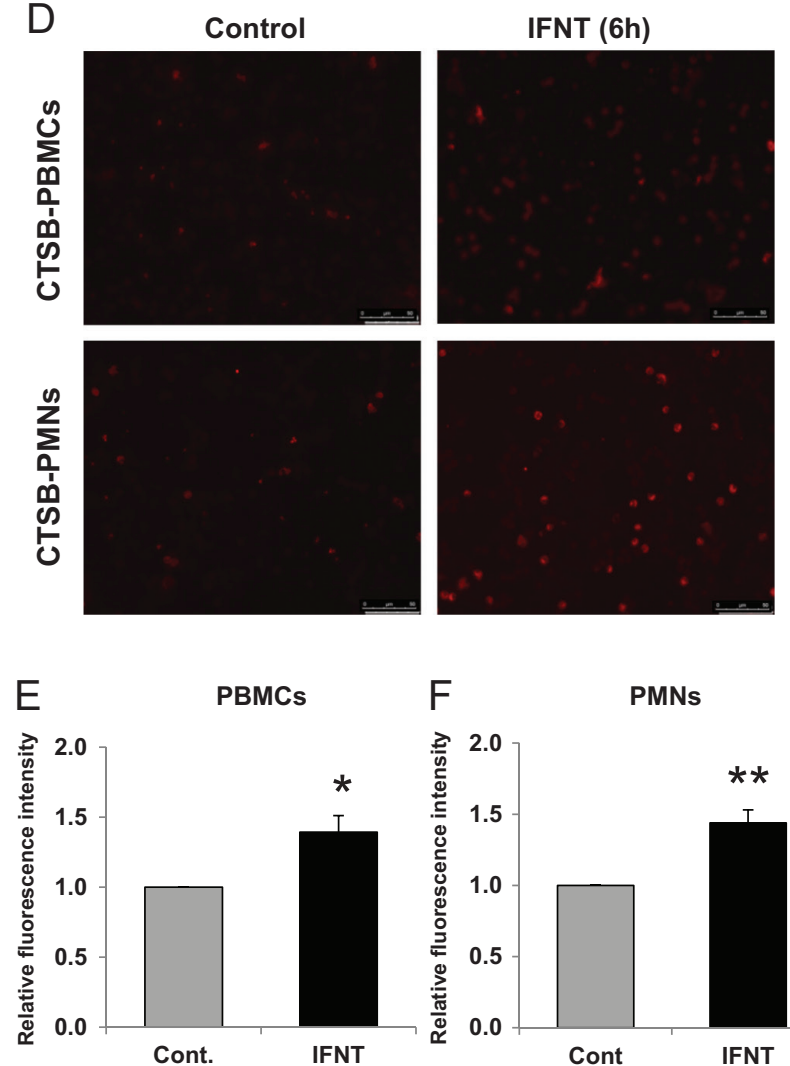

(6h)
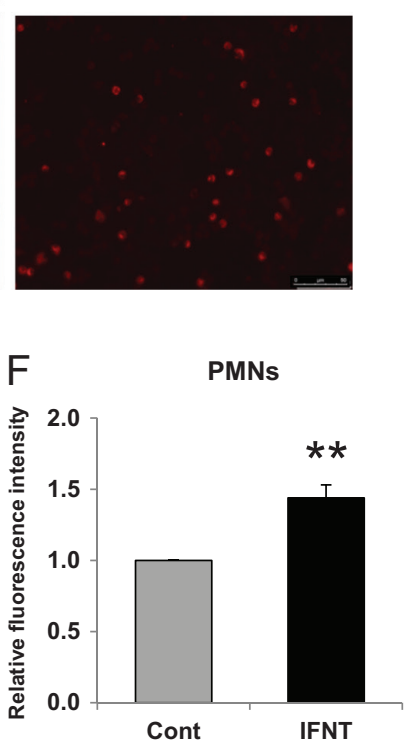

(6h)

Figure 7 Immunostaining and detection of CTSB protein in in-vivo-collected pregnant/ non-pregnant and IFNT-stimulated of non-pregnant PBMCs and PMNs. Immunohistochemical localization of the CTSB protein in PBMCs and PMNs collected from d18 pregnant (P) and nonpregnant (NP) cows (A), relative fluorescent levels of CTSB in PBMCs (B) and PMNs (C). Immunohistochemical localization of the CTSB protein in control and IFNT-treated PBMCs and PMNs, relative fluorescent levels of CTSB in PBMCs (E) and PMNs (F). The images were captured with a fluorescence microscope using a 590-nm excitation filter at 400x. The scale bar represents $50 \mu \mathrm{m}$. Six cows ( 3 for pregnant and 3 for nonpregnant) were used for the analysis. In vitro stimulation was repeated 3 times. Asterisks $\left({ }^{* * *} P<0.0001,{ }^{*} P<0.01,{ }^{*} P<0.05\right.$, Student's $t$ test) indicate differences in non-pregnant (NP) vs pregnant (P) or control vs IFNT stimulation.

CTSB and CTSK are lysosomal proteases capable of digesting matrix proteins and activating other proteases involved in matrix degradation (Kirschke et al. 1998). CTSs participate in the bulk degradation of proteins within the lysosomes, but many CTSs have also been shown to be critically involved in distinct physiological processes, including bone remodeling, protein processing, antigen presentation, degradation of extracellular matrix and initiation of cell death (Reiser et al. 2010, Turk et al. 2012). CTSs are predominantly endopeptidases and are relatively nonspecific enzymes. Lysosomal proteases such as CTS activity are regulated by certain cytokines. Fiebiger et al. (2001) reported that CTSs $S$ and B activity increased in human dendritic cells (DCs) in response to cytokines such as TNF alpha and IL1 beta, leading to increased class $2 \mathrm{MHC}$ dimer formations and $\mathrm{T}$ cell recognition. Altering endosomal $\mathrm{pH}$ and lysosomal protease activity can be modulated by cytokines such as IL6 and IL10 (Drakesmith et al. 1998, Fiebiger et al. 2001).
The present study indicated that type 1 interferon (that is, IFNT) increased the activity of CTSs. IFNT might have affected CTSs by different mechanisms than TNF alpha and IL1 beta. Sendide et al. (2005) showed that CTS activity, enhanced by IL10 and IL6, leads to improved presentation and recognition of $\mathrm{T}$ cell epitopes in IL-treated DCs.

The differences in the expression of CTSB and CTSK genes in pregnant and NP cows suggest functional diversity in the immune cell mechanisms responsible for the expression of CTSs genes that support implantation and placentation during the establishment and maintenance of pregnancy. The results of the present study support the hypothesis that CTSs are dynamically expressed in pregnant bovine PBLs and that they play important roles in the implantation, placentation and growth of the conceptus. In the present study, CTSB activity and gene expression were increased both in pregnant d18 and IFN-induced cultured PBMCs and PMNs. This indicates the IFNT-induced up-regulation 
A
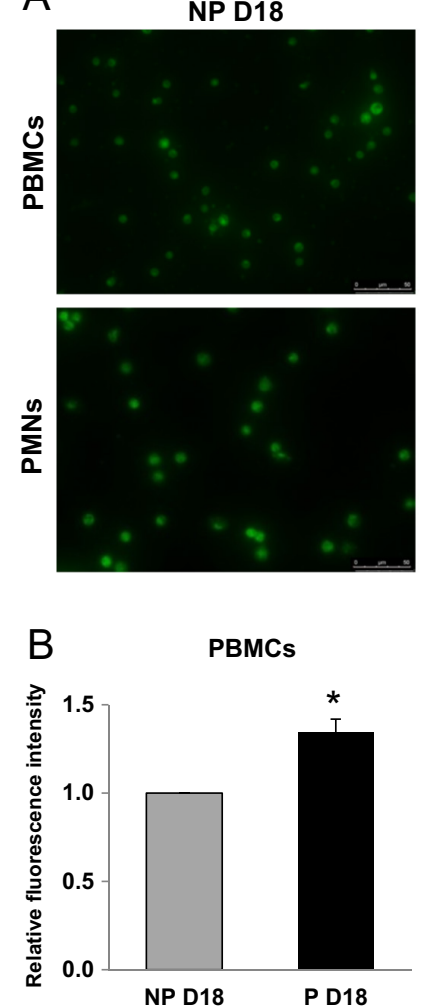

P D18
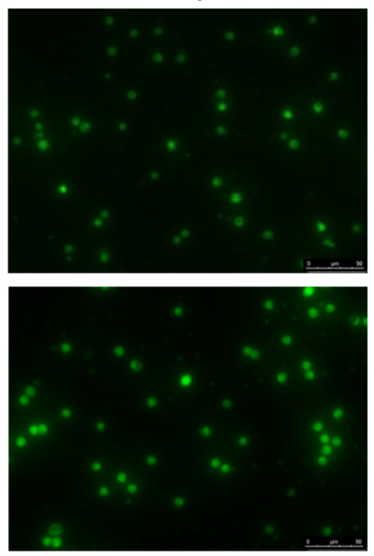

C

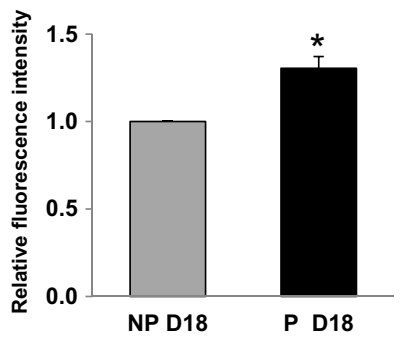

D
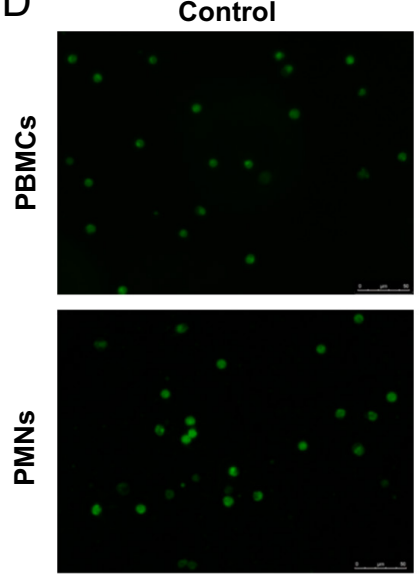

E

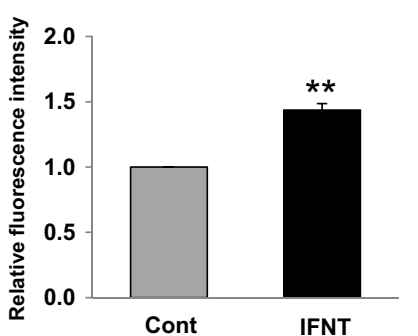

(6h)
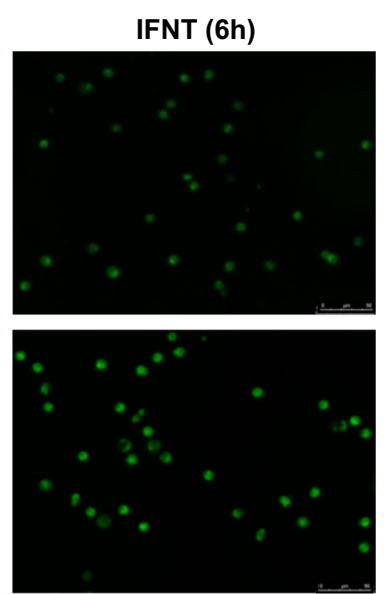

F PMNs

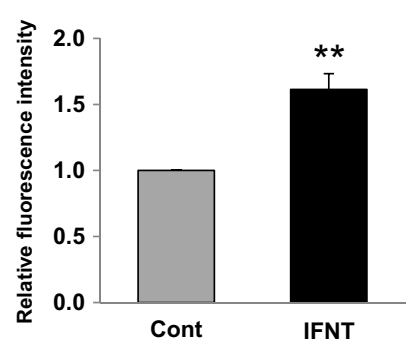

(6h)

Figure 8 Lysosomal activity in in-vivo-collected pregnant/non-pregnant and IFNT-stimulated PBMCs and PMNs. Fluorescence image of lysosomal acidification in PBMCs and PMNs collected from d18 pregnant (P) and non-pregnant (NP) cows (A), relative fluorescent levels of lysosomal activity in PBMCs (B) and PMNs (C). Fluorescence image of lysosomal acidification in control and IFNT-treated PBMCs and PMNs in vitro (D), relative fluorescent levels of lysosomal activity in PBMCs (E) and PMNs (F). The lysosomal acidifications were detected with the lysosensor using a 590-nm excitation filter at 400x. The scale bar represents $50 \mu \mathrm{m}$. Six cows ( 3 for pregnant and 3 for non-pregnant) were used for the analysis. In vitro stimulation was repeated 3 times. All data are shown as the mean \pm standard error of the mean (S.E.M.). Asterisks $\left({ }^{* *} P<0.05\right.$, Student's $t$ test $)$ indicate difference between the control and IFNT treatment groups.

pathway of the CTSB gene followed by an increase of the protein, as well as CTSB activity and gene expression. However, despite high activity of CTSK in PBMCs and PMNs both in pregnant $\mathrm{d} 18$ and IFN-stimulated cells, gene expression was not clearly affected by pregnancy or IFN stimulation. The different expression patterns of CTSs B, K, L and S are reported in osteoclasts (Ishibashi et al. 2001) even though CTSB and CTSK belong to same cysteine protease. In vitro, CTSB and CTSK mRNA levels in PBMCs increased significantly after 3 and $6 \mathrm{~h}$ of IFNT stimulation, compared to the control group. Also, in PMNs, these mRNA levels significantly increased at 3-, 6- and 12-h time intervals in the IFNT-stimulated group compared to the control group. Emond et al. (2000) showed that, in vitro, IFNT stimulated the independent gene expression pattern of a granulocyte macrophage colony stimulating factor in bovine leukocytes and endometrial stromal cells independently.

Cysteine CTSs are optimally active in a slightly acidic $\mathrm{pH}$, becoming mostly unstable at a neutral $\mathrm{pH}$, and different CTSs have different activation conditions (Turk et al. 2012). Similar intracellular processing of
CTSK is also reported (Dodds et al. 2001). Therefore, the different gene expression patterns of CTSK and CTSB may not correlate with enzymatic activities. In addition, detection of fluorescent activity was achieved with different fluorescent substrates for CTSB and CTSK. Thus, another possible explanation for the non-correlation with CTSK mRNA levels and fluorescence generated by digestion of fluorescent substrate is the fluorescence intensity caused by excitation strength or the amount of conjugated fluorescent dyes. In the case of CTSB activity, protein synthesis and gene expression were increased in the PBMCs and PMNs on $\mathrm{d} 18$ of pregnancy in vivo and after IFNT stimulation in vitro. CTSB could be a potential marker for pregnancy detection in the blood cells.

Interestingly, in the present study, clear activation of lysosomes by increasing acidification was detected, as well as the increase of gene expression of LAMP1 and LAMP2 in pregnant PBLs. Lysosomes are membranebound dynamic organelles that are indispensable for endocytosis, phagocytosis and autophagy (Eskelinen et al. 2003). Lysosomes contain enzymes that breakdown unused intracellular materials, such as acid hydrolyses 

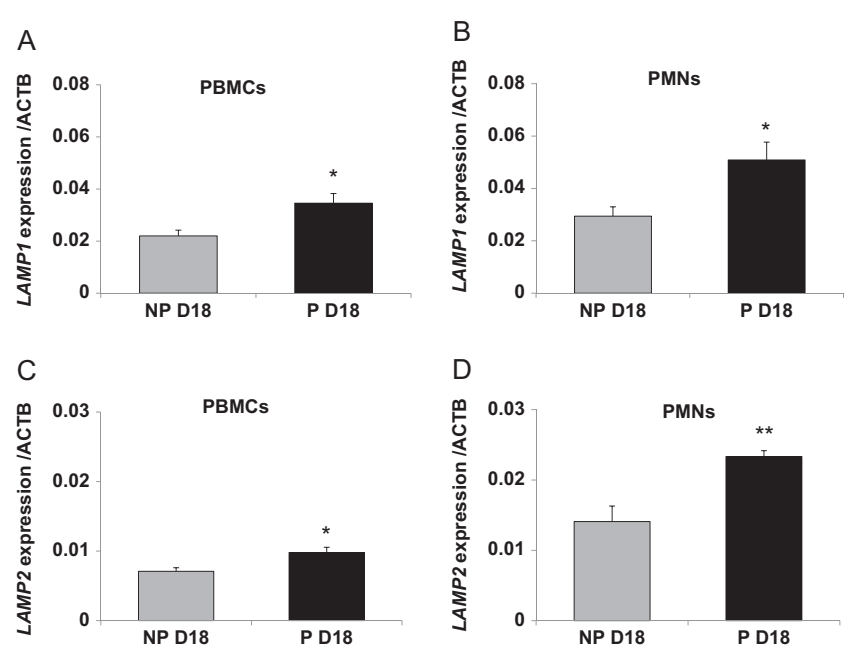

Figure 9 Expression of $L A M P 1$ and $L A M P 2$ mRNA in pregnant and non-pregnant PBMCs and PMNs. The graphs show the expression levels of $\angle A M P 1$ in PBMCs (A) and PMNs (B), and of LAMP2 in PBMCs (C) and PMNs (D) collected from pregnant and non-pregnant d 18 cows using RT-qPCR, standardized with the reference gene $A C T B$. Asterisks indicate differences for $L A M P 1\left({ }^{*} P<0.05\right)$ and for LAMP2 $\left({ }^{*} P<0.05,{ }^{* *} P<0.01\right)$ between non-pregnant $(\mathrm{NP})$ and pregnant $(\mathrm{P})$ cows after $\mathrm{Al}$, determined by Student's $t$ test.

synthesized in the endoplasmic reticulum and packaged in the Golgi complex into so-called primary lysosomes. These lysosomes fuse with endosomes to form endolysosomes or secondary lysosomes; hydrogen ions then create an acidic environment and activate the enzymes. Thus, mature and active lysosomes are characterized by a highly acidic $\mathrm{pH}$ and activated hydrolytic enzyme are formed (Singh 2011). Lysosomes contain many different types of hydrolytic enzymes, including CTSs, expressing their maximum enzymatic activity at low $\mathrm{pH}$ maintained by active proton pumps. The acidic condition of lysosomes is maintained by a vacuolar ATPase that pumps protons from the cytosol into the lysosomal lumen (Luzio et al. 2007). LAMP1 and LAMP2 are major lysosomal transmembrane proteins which regulate lysosomal functions including acidification (Saftig \& Klumperman 2009). Therefore, the increase of lysosomal acidification as well as CTS activity caused by low $\mathrm{pH}$ can be explained by an increase of LAMP1 and LAMP2, followed by an increase of functional lysosomal membrane activation. Stimulation of lysosomal function by IFNB as well as activation of CTSs in mouse bone marrow-derived macrophages has been reported (Creasy et al. 2011).

However, there are currently no reports discussing the direct effect of IFNT on lysosomal activation mechanisms associated with the roles of lysosomal membrane proteins. MxA, a type 1 IFN-stimulated gene (protein), co-localizes with LAMP1 in lysosomes of MxA expressing cells (Stertz et al. 2006). This indicates that lysosomal activation by lysosomal membrane proteins may be functional with ISG via a type 1 IFN pathway in pregnant bovine leukocytes. It is still necessary to clarify the mechanisms.

In conclusion, the present study first showed the activation of lysosomes and CTS enzymes in PBLs at the time of maternal and fetal recognition of pregnancy and that their activation is mediated by IFNT. These findings suggest a possible marker for potential early pregnancy detection.

\section{Supplementary data}

This is linked to the online version of the paper at https://doi.org/10.1530/REP-18-0078.

\section{Declaration of interest}

The authors declare that there is no conflict of interest that could be perceived as prejudicing the impartiality of the research reported.

\section{Funding}

This study was supported by a Grant-in-Aid for Scientific Research from the Japan Society for the Promotion of Science (KAKENHI, 15H04579) and by the Cooperative Research Program for Agriculture Science \& Technology Development (RDAPJ01029305).

\section{Acknowledgements}

We are grateful to all members and technical staff of Hokkaido University Dairy Farm for continuous support for blood sampling. We would like to thank Editage (www.editage.jp) for English language editing.

\section{References}

Abbitt B, Ball L, Kitto GP, Sitzman CG, Wilgenburg B, Raim LW \& Seidel GE JR 1978 Effect of three methods of palpation for pregnancy diagnosis per rectum on embryonic and fetal attrition in cows. Journal of the American Veterinary Medical Association 173 973-977.

Afonso S, Romagnano L \& Babiarz B 1997 The expression and function of cystatin $C$ and cathepsin B and cathepsin $L$ during mouse embryo implantation and placentation. Development 12 3415-3425.

Bazer FW 2013 Pregnancy recognition signaling mechanisms in ruminants and pigs. Journal of Animerican Science and Biotechnology 4 23. (https:// doi.org/10.1186/2049-1891-4-23)

Bazer FW, Thatcher WW, Hansen PJ, Mirando MA, Ott TL \& Plante C 1991 Physiological mechanisms of pregnancy recognition in ruminants. Journal of Reproduction and Fertility Supplement 43 39-47.

Bromme D \& Okamoto K 1995 Human cathepsin O2, a novel cysteine protease highly expressed in osteoclastomas and ovary: molecular cloning, sequencing and tissue distribution. Biological Chemistry HoppeSeyler 376 379-384. (https://doi.org/10.1515/bchm3.1995.376.6.379)

Creasy BM \& McCoy KL 2011 Cytokines regulate cysteine cathepsins during TLR responses. Cellular Immunology 267 56-66. (https://doi. org/10.1016/j.cellimm.2010.11.004)

Darnel JE JR, Keri IM \& Stark GR 1994 JAK-STAT pathways and transcriptional activation in response to IFNs and other extracellular signaling proteins. Science 264 1415-1421. (https://doi.org/10.1126/ science.8197455) 
Der SD, Zhou A, Williams BR \& Silverman RH 1998 Identification of genes differentially regulated by interferon alpha, beta, or gamma using oligo nucleotide arrays. PNAS 95 15623-15628. (https://doi.org/10.1073/ pnas.95.26.15623)

Dodds RA, James IE, Rieman D, Ahern R, Hwang SM, Connor JR, Thompson SD, Veber DF, Drake FH, Holmes S et al. 2001 Human osteoclast cathepsin $\mathrm{K}$ is processed intracellularly prior to attachment and bone resorption. Journal of Bone and Mineral Research 16 478-486. (https://doi.org/10.1359/jbmr.2001.16.3.478)

Drakesmith H, O'Neil D, Schneider SC, Binks M, Medd P \& Sercarz E 1998 In vivo priming of $\mathrm{T}$ cells against cryptic determinants by dendritic cells exposed to interleukin 6 and native antigen. PNAS 95 14903-14908. (https://doi.org/10.1073/pnas.95.25.14903)

Emond V, Asselin E, Fortier MA, Murphy BD \& Lambert RD 2000 Interferon-tau stimulates granulocytes macrophase colony stimulating factor gene expression in bovine lymphocytes and endometrial stromal cells. Biology of Reproduction 62 1728-1737. (https://doi.org/10.1095/ biolreprod62.6.1728)

Eskelinen EL, Tanaka Y \& Saftig P 2003 At the acidic edge, emerging functions for lysosomes membrane proteins. Trends in Cell Biology 13 137-145. (https://doi.org/10.1016/S0962-8924(03)00005-9)

Fiebiger E, Meraner P, Weber E, Fang IF, Stingl G \& Ploegh H 2001 Cytokines regulate proteolysis in major histocompatibility complex class II-dependent antigen presentation by dendritic cells. Journal of Experimental Medicine 193 881-892. (https://doi.org/10.1084/ jem.193.8.881)

Fricke PM 2002 Scanning the future-ultrasonography as a reproductive management tool for dairy cattle. Journal of Dairy Science 85 1918-1926. (https://doi.org/10.3168/jds.S0022-0302(02)74268-9)

Gifford CA, Racicot K, Clark DS, Austin KJ, Hansen TR, Lucy MC, Davies CJ \& Ott TL 2007 Regulation of interferon-stimulated genes in peripheral blood leukocytes in pregnant and bred, non pregnant dairy cows. Journal of Dairy Science 90 274-280. (https://doi.org/10.3168/jds. S0022-0302(07)72628-0)

Geisert RD, Blair RM, Pratt T \& Zavy MT 1997 Characterization and proteolytic activity of a cathepsin L-like polypeptide in endometrium and uterine flushing's of cycling, pregnant and steroid-treated ovariectomized gilts. Reproduction Fertility and Development 9 395-402. (https://doi. org/10.1071/R96106)

Green JC, Okamura CS, Poock SE \& Lucy MC 2010 Measurement of interferon-tau (IFN $\tau$ ) stimulated gene expression in blood leukocytes for pregnancy diagnosis within 18-20d after insemination in dairy cattle. Animal Reproduction Science 121 24-33. (https://doi.org/10.1016/j. anireprosci.2010.05.010)

Hamilton RT, Bruns KA, Delgado MA, Shim JK, Fang Y \& Denhardt DT 1991 Developmental expression of cathepsin L and C-rasHa in the mouse placenta. Molecular Reproduction and Development 30 285-292. (https://doi.org/10.1002/mrd.1080300402)

Han H, Austin KJ, Rempel LA \& Hansen TR 2006 Low blood ISG15 mRNA and progesterone levels are predictive of non-pregnant dairy cows. Journal of Endocrinology 191 505-512. (https://doi.org/10.1677/ joe.1.07015)

Hicks BA, Etter SJ, Carnahan KG, Joyce MM, Assiri AA, Carling SJ, Kodali K, Johnson GA, Hansen TR, Mirando MA et al. 2003 Expression of the uterine $M x$ protein in cyclic and pregnant cows, gilts, and mares. Journal of Animal Science 81 1552-1561. (https://doi. org/10.2527/2003.8161552x)

Imakawa K, Anthony RV, Kazemi M, Marotti KR, Polites HG \& Roberts RM 1987 Interferon-like sequence of ovine trophoblast protein secreted by embryonic trophectoderm. Nature 330 377-379. (https://doi. org/10.1038/330377a0)

Ishibashi O, Inui T, Mori Y, Kurokawa T, Kokubo T \& Kumegawa M 2001 Quantification of the expression levels of lysosomal cysteine proteinases in purified human osteoclastic cells by competitive RT-PCR. Calcified Tissue International 68 109-116. (https://doi.org/10.1007/BF02678149)

Ishida M, Ono K, Taguchi S, Ohashi S, Naito J \& Horiguchi K 2004 Cathepsins gene expression in mouse placenta during the latter half of pregnancy. Journal of Reproduction and Development 50 515-523. (https://doi.org/10.1262/jrd.50.515)

Kirschke H, Barrett AJ \& Rawlings ND 1998 Lysosomal cysteine proteases. In Protein Profile Series, 2nd ed. Ed P Sheterline. New York: Oxford University Press.
Li WG, Jaffe RC, Fazleabas AT \& Verhage HG 1991 Progesterone-dependent cathepsin L proteolytic activity in cat uterine flushing's. Biology of Reproduction 44 625-631. (https://doi.org/10.1095/biolreprod44.4.625)

Luzio JP, Pryor PR \& Bright NA 2007 Lysosomes: fusion and function. Nature Reviews Molecular Cell Biology 8 622-632. (https://doi. org/10.1038/nrm2217)

Mann GE, Lamming GE, Robinson RS \& Wathes DC 1999 The regulation of interferon-tau production and uterine hormone receptors during early pregnancy. Journal of Reproduction and Fertility Supplement $\mathbf{5 4}$ 317-328.

Morton JM \& Wynn PC 2010 Assessing ovulation detection performance in commercial dairy herds using progesterone concentrations from limited numbers of strategically collected milk samples. Journal of Dairy Science 93 3019-3030. (https://doi.org/10.3168/jds.2009-2938)

Nakao T, Sugihashi A, Kawata K, Saga N \& Tsunoda N 1983 Milk progesterone levels in cows with normal or prolonged estrous cycles, referenced to an early pregnancy diagnosis. Japanese Journal of Veterinary Science 45 495-499. (https://doi.org/10.1292/jvms1939.45.495)

Okumu LA, Forde N, Fahey AG, Fitzpatrick E, Roche JF, Crowe MA \& Lonergan P 2010 The effect of elevated progesterone and pregnancy status on mRNA expression and localization of progesterone and estrogen receptors in the bovine uterus. Reproduction 140 143-153. (https://doi.org/10.1530/REP-10-0113)

Oliveira JF, Henkes LE, Ashley RL, Purcell SH, Smirnova NP, Veeramachaneni DN, Anthony RV\& Hansen TR 2008 Expression of interferon (IFN)-stimulated genes in extra uterine tissues during early pregnancy in sheep is the consequence of endocrine IFN-tau release from the uterine vein. Endocrinology 149 1252-1259. (https://doi. org/10.1210/en.2007-0863)

Ott TL, Yin J, Wiley AA, Kim H, Gerami-Naini B, Spencer TE, Bartol FF, Burghardt RC \& Bazer FW 1998 Effects of the estrous cycle and early pregnancy on uterine expression of $\mathrm{Mx}$ protein in sheep (Ovis aries). Biology of Reproduction 59 784-794. (https://doi.org/10.1095/ biolreprod59.4.784)

Petanceska S \& Devi L 1992 Sequence analysis, tissue distribution, and expression of rat cathepsin S. Journal of Biological Chemistry 267 26038-26043.

Platanias LC 2005 Mechanisms of type I and type II interferon stimulated signaling. Nature Reviews Immunology I5 375-386. (https://doi. org/10.1038/nri1604)

Pugliesi G, Miagawa BT, Paiva YN, França MR, Silva LA \& Binelli M 2014 Conceptus induced changes in the gene expression of blood immune cells and the ultrasound-accessed luteal function in beef cattle: how early can we detect pregnancy? Biology of Reproduction 91 1-2.

Rantakokko J, Aro HT \& Savontaus M 1996 Mouse cathepsin K: cDNA cloning and predominant expression of the gene in osteoclasts and in some hypertrophying chondrocytes during mouse development. FEBS Letters 16 307-313. (https://doi.org/10.1016/0014-5793(96)00907-6)

Reiser J, Adair B \& Reinheckel T 2010 Specialized roles for cysteine cathepsins in health and disease. Journal of Clinical Investigation $\mathbf{1 2 0}$ 3421-3431. (https://doi.org/10.1172/JCl42918)

Rizos D, Gutiérrez-Adán A, Pérez-Garnelo S, De La Fuente J, Boland MP \& Lonergan P 2003 Bovine embryo culture in the presence or absence of serum: implications for blastocyst development, cryotolerance, and messenger RNA expression. Biology of Reproduction 68 236-243. (https://doi.org/10.1095/biolreprod.102.007799)

Roberts RM, Ealy AD, Alexenko AP, Han CS \& Ezashi T 1999 Trophoblast $\begin{array}{llll}\text { interferons. Placenta } 20 & 259-264 . & \text { (https://doi.org/10.1053/ }\end{array}$ plac.1998.0381)

Romano JE, Thompson JA, Kraemer DC, Westhusin ME, Forrest DW \& Tomaszweski MA 2007 Early pregnancy diagnosis by palpation per rectum: influence on embryo/fetal viability in dairy cattle. Theriogenology 67 486-493. (https://doi.org/10.1016/j.theriogenology.2006.08.011)

Rossi A, Deveraux Q, Turk B \& Sali A 2004 Comprehensive search for cysteine cathepsins in the human genome. Biological Chemistry 385 $363-72$.

Saftig P \& Klumperman J 2009 Lysosome biogenesis and lysosomal membrane proteins: trafficking meets function. Nature Reviews Molecular Cell Biology 10 623-635. (https://doi.org/10.1038/nrm2745)

Sendide K, Deghmane AE, Pechkovsky D, AV Gay Y, Talal A \& Hmama Z 2005 Mycobacterium bovis BCG attenuates surface expression of mature class II molecules through IL-10-dependent inhibition of cathepsin 
S. Journal of Immunology 175 5324-5332. (https://doi.org/10.4049/ jimmunol.175.8.5324)

Shirasuna K, Matsumoto H, Kobayashi E, Nitta A, Haneda S, Matsui M, Kawashima C, Kida K, Shimizu T \& Miyamoto A 2012 Up-regulation of interferon-stimulated genes and interleukin-10 in peripheral blood immune cells during early pregnancy in dairy cows. Journal of Reproduction and Development 58 84-90. (https://doi.org/10.1262/ jrd.11-094K)

Singh I 2011 Textbook of Human Histology: (With Colour Atlas and Practical Guide), pp 386. New Delhi, St Louis: Jaypee Brothers Medical Publishers.

Song G, Spencer TE \& Bazer FW 2005 Cathepsins in the ovine uterus: regulation by pregnancy, progesterone, and interferon tau. Endocrinology 146 4825-4833. (https://doi.org/10.1210/en.2005-0768)

Soderstrom M, Salminen H \& Glumoff V 1999 Cathepsin expression during skeletal development. Biochimica et Biophysica Acta 7 35-46. (https://doi.org/10.1016/S0167-4781(99)00068-8)

Stertz S, Reichelt M, Krijnse-Locker J, Mackenzie J, Simpson JC, Haller O \& Kochs G 2006 Interferon-induced, antiviral human MxA protein localizes to a distinct subcompartment of the smooth endoplasmic reticulum. Journal of Interferon and Cytokine Research 26 650-660. (https://doi.org/10.1089/jir.2006.26.650)

Stevenson JL, Dalton JC, Ott TL, Racicot KE \& Chebel RC 2007 Correlation between reproductive status and steady-state messenger ribonucleic acid levels of the Myxo virus resistance gene, Mx2, in peripheral blood leukocytes of dairy heifers. Journal of Animal Science 85 2163-2172. (https://doi.org/10.2527/jas.2007-0014)

Thatcher WW, Meyer MD \& Danet-Desnoyers G 1995 Maternal recognition of pregnancy. Journal of Reproduction and Fertility Supplement 49 15-28.

Turk B, Turk D \& Turk V 2000 Lysosomal cysteine proteases: more than scavengers. Biochimica et Biophysica Acta 1477 98-111. (https://doi. org/10.1016/S0167-4838(99)00263-0)
Turk B, Turk D \& Turk V 2001 Lysosomal cysteine proteases: facts and opportunities. EMBO Journal 20 4629-4633. (https://doi.org/10.1093/ emboj/20.17.4629)

Turk V, Stoka V, Vasiljeva O, Renko M, Sun T \& Turk B 2012 Cysteine cathepsins: from structure, function and regulation to new frontiers. Biochimica et Biophysica Acta 1824 68-88. (https://doi.org/10.1016/j. bbapap.2011.10.002)

Vaillancourt D, Bierschwal CJ, Ogwu D, Elmore RG, Martin CE, Sharp AJ \& Youngquist RS 1979 Correlation between pregnancy diagnosis by membrane slip and embryonic mortality. Journal of the American Veterinary Medical Association 175 466-468.

Verhage HG, Boomsma RA, Mavrogianis PA, Li W, Fazleabas AT \& Jaffle RC 1989 Immunological characterization and immuno cytochemical localization of a progesterone-dependent cat endometrial secretory protein. Biology of Reproduction 41 347-354. (https://doi.org/10.1095/ biolreprod41.2.347)

Walter I \& Schonkypl S 2006 Extracellular matrix components and matrix degrading enzymes in the feline placenta during gestation. Placenta $\mathbf{2 7}$ 291-306. (https://doi.org/10.1016/j.placenta.2005.02.014)

Zoli AP, Guilbault LA, Delahaut P, Ortiz WB \& Beckers JF 1992 Radioimmuno assay of a bovine pregnancy-associated glycoprotein in serum: its application for pregnancy diagnosis. Biology of Reproduction 46 83-92. (https://doi.org/10.1095/biolreprod46.1.83)

Received 15 February 2018

First decision 20 March 2018

Revised manuscript received 27 March 2018

Accepted 6 April 2018 